\title{
Bensingtonia rectispora sp. nov. and Bensingtonia bomiensis sp. nov., ballistoconidium-forming yeast species from Tibetan plant leaves
}

Correspondence

Feng-Yan Bai

baify@im.ac.cn
Qi-Ming Wang, ${ }^{1}$ Teun Boekhout ${ }^{2}$ and Feng-Yan Bai ${ }^{1}$

\author{
${ }^{1}$ State Key Laboratory of Mycology, Institute of Microbiology, Chinese Academy of Sciences, \\ Beijing 100101, PR China \\ ${ }^{2}$ CBS Fungal Diversity Centre, Royal Netherlands Academy of Arts and Sciences, 3584 CT Utrecht, \\ The Netherlands
}

\begin{abstract}
Five yeast strains isolated from plant leaves collected in south-east Tibet formed cream to brownish colonies and produced asymmetrical ballistoconidia and CoO-9 as the major ubiquinone. Sequence analysis of the 26S rRNA D1/D2 domain and the internal transcribed spacer region indicated that these strains represented two novel species of the genus Bensingtonia. The names Bensingtonia rectispora sp. nov. (type strain $\mathrm{XZ} 4 \mathrm{C} 5^{\mathrm{T}}=\mathrm{CGMCC}$ $2.02635^{\top}=\mathrm{CBS} 10710^{\top}$ ) and Bensingtonia bomiensis sp. nov. (type strain $\mathrm{XZ} 33 \mathrm{D} 1^{\top}=\mathrm{CGMCC}$ $2.02670^{\top}=$ CBS $10713^{\top}$ ) are proposed for the two novel species, which are phylogenetically closely related to Bensingtonia naganoensis, Bensingtonia pseudonaganoensis and the type species of the genus, Bensingtonia ciliata.
\end{abstract}

The genus Bensingtonia was described by Ingold (1986) and emended by Nakase \& Boekhout (1988) to accommodate basidiomycetous yeasts characterized by the production of ballistoconidia, the formation of CoQ-9 as the major ubiquinone and the absence of xylose in the cell wall (Nakase et al., 2011). The genus is highly polyphyletic though only 15 species are currently recognized (Takashima et al., 1995; Fell et al., 2000; Hamamoto \& Nakase, 2000; Scorzetti et al., 2002; Wang et al., 2003, 2006; Nakase et al., 2011). Thirteen Bensingtonia species, including the type species Bensingtonia ciliata, belong to the Agaricostilbales in the Agaricostilbomycetes, whereas the other two species, Bensingtonia yamatoana and Bensingtonia intermedia (Mastigobasidium intermedium), are located in separate lineages of the Microbotryomycetes (Boekhout et al., 2011; Nakase et al., 2011). The Bensingtonia species in the Agaricostilbales occur in at least four different lineages or clades intermingled with species of Agaricostilbum, Kondoa and Sterigmatomyces (Fell et al., 2000; Scorzetti et al., 2002; Wang et al., 2003, 2006; Boekhout et al., 2011; Nakase et al., 2011). Only two species, Bensingtonia naganoensis and Bensingtonia pseudonaganoensis, cluster together with the type species ( $B$. ciliata) in a strongly supported clade (Wang et al., 2006; Nakase et al., 2011). Reclassification of Bensingtonia and related genera will be necessary in the

Abbreviation: ITS, internal transcribed spacer.

The GenBank/EMBL/DDBJ accession numbers for the ITS region and 26S rRNA gene D1/D2 domain sequences of strains $X Z 4 C 5^{\top}, X Z$ 5C1-D, XZ 9C3-D, XZ 14B3-2 and XZ 33D1 $1^{\top}$ are JN620351JN620355, respectively. future and the addition of novel species to the B. ciliata clade will be valuable for both phenotypic and phylogenetic redefinition of the genus.

In recent years, we have been investigating phyllosphere yeast diversity. Of the ballistoconidium-forming yeast strains isolated from Tibet, five strains that formed bilaterally symmetrical ballistoconidia and possessed CoQ-9 as the major ubiquinone were isolated; studies revealed that these strains represent two novel Bensingtonia species closely related to the type species $B$. ciliata.

Strains XZ 4C5 ${ }^{\mathrm{T}}$, XZ 5C1-D, XZ 9C3-D, XZ 14B3-2 and XZ $33 \mathrm{D} 1^{\mathrm{T}}$ (Table 1 ) were all isolated from wilting plant leaves collected from mixed coniferous and broad leaved forests in Nyingchi (coordinates: $30^{\circ} 17^{\prime} \mathrm{N} 94^{\circ} 40^{\prime} \mathrm{E}$ ) and Bomi (coordinates: $30^{\circ} 48^{\prime} \mathrm{N} 95^{\circ} 44^{\prime} \mathrm{E}$ ) counties, south-east Tibet, China, in July 2004, by using the improved ballistoconidiafall method as described by Nakase \& Takashima (1993). The two counties are adjacent, are approximately $3000 \mathrm{~m}$ above sea-level and have similar climates, with mean annual temperatures of $8-9{ }^{\circ} \mathrm{C}$ and annual precipitation of 600 $900 \mathrm{~mm}$. Most of the morphological, physiological and biochemical characteristics were examined according to standard methods (Kurtzman et al., 2011). Assimilation of nitrogen compounds was investigated on solid media with starved inocula (Nakase \& Suzuki, 1986). Extraction, purification and identification of ubiquinones were carried out according to Yamada \& Kondo (1973).

Nuclear DNA was extracted by using the method of Makimura et al. (1994). The internal transcribed spacer 
Table 1. Yeast strains studied

\begin{tabular}{|c|c|c|}
\hline Species & Strain & Source \\
\hline \multirow[t]{4}{*}{ Bensingtonia rectispora sp. nov. } & $\mathrm{XZ} 4 \mathrm{C} 5^{\mathrm{T}}=\mathrm{CGMCC} 2.02635^{\mathrm{T}}=\mathrm{CBS} 10710^{\mathrm{T}}$ & Wilting leaf of bamboo, Nyingchi county, Tibet \\
\hline & $\mathrm{XZ}$ 5C1-D=CGMCC 2.02656 & $\begin{array}{l}\text { Wilting leaf of Rhododendron phaeochrysum, Nyingchi } \\
\text { county, Tibet }\end{array}$ \\
\hline & $\mathrm{XZ}$ 9C3-D=CGMCC 2.02657 & Wilting leaf of Sorbaria arborea, Nyingchi county, Tibet \\
\hline & $\mathrm{XZ}$ 14B3-2=CGMCC 2.02669 & Wilting leaf of bamboo, Nyingchi county, Tibet \\
\hline Bensingtonia bomiensis sp. nov. & $\mathrm{XZ} 33 \mathrm{D} 1^{\mathrm{T}}=$ CGMCC $2.02670^{\mathrm{T}}=\mathrm{CBS} 10713^{\mathrm{T}}$ & Wilting leaf of an unidentified plant, Bomi county, Tibet \\
\hline
\end{tabular}

(ITS) (including 5.8S rRNA) region and 26S rRNA gene D1/D2 domain sequences were obtained by using the methods described by Bai et al. (2002). Sequences were aligned with the program CLUSTAL_X (Thompson et al., 1997). Phylogenetic trees were reconstructed by using the neighbour-joining method (Saitou \& Nei, 1987) with the evolutionary distance data calculated from Kimura's twoparameter model (Kimura, 1980). Bootstrap analyses (Felsenstein, 1985) were performed from 1000 random resamplings.

\section{Molecular phylogeny}

Two groups were recognized from the five strains studied by rRNA gene sequence analysis. The four strains $\mathrm{XZ} 4 \mathrm{C} 5^{\mathrm{T}}$, $\mathrm{XZ}$ 5C1-D, XZ 9C3-D and XZ 14B3-2, which were isolated from Nyingchi, exhibited identical D1/D2 and ITS sequences. They differed significantly from strain XZ $33 \mathrm{D} 1^{\mathrm{T}}$, which was isolated from Bomi, in sequences of both rRNA gene regions (Fig. 1). In the phylogenetic tree constructed from neighbour-joining analysis of the combined ITS and D1/D2 sequences, strains $\mathrm{XZ} 4 \mathrm{C}^{\mathrm{T}}$ and $\mathrm{XZ}$

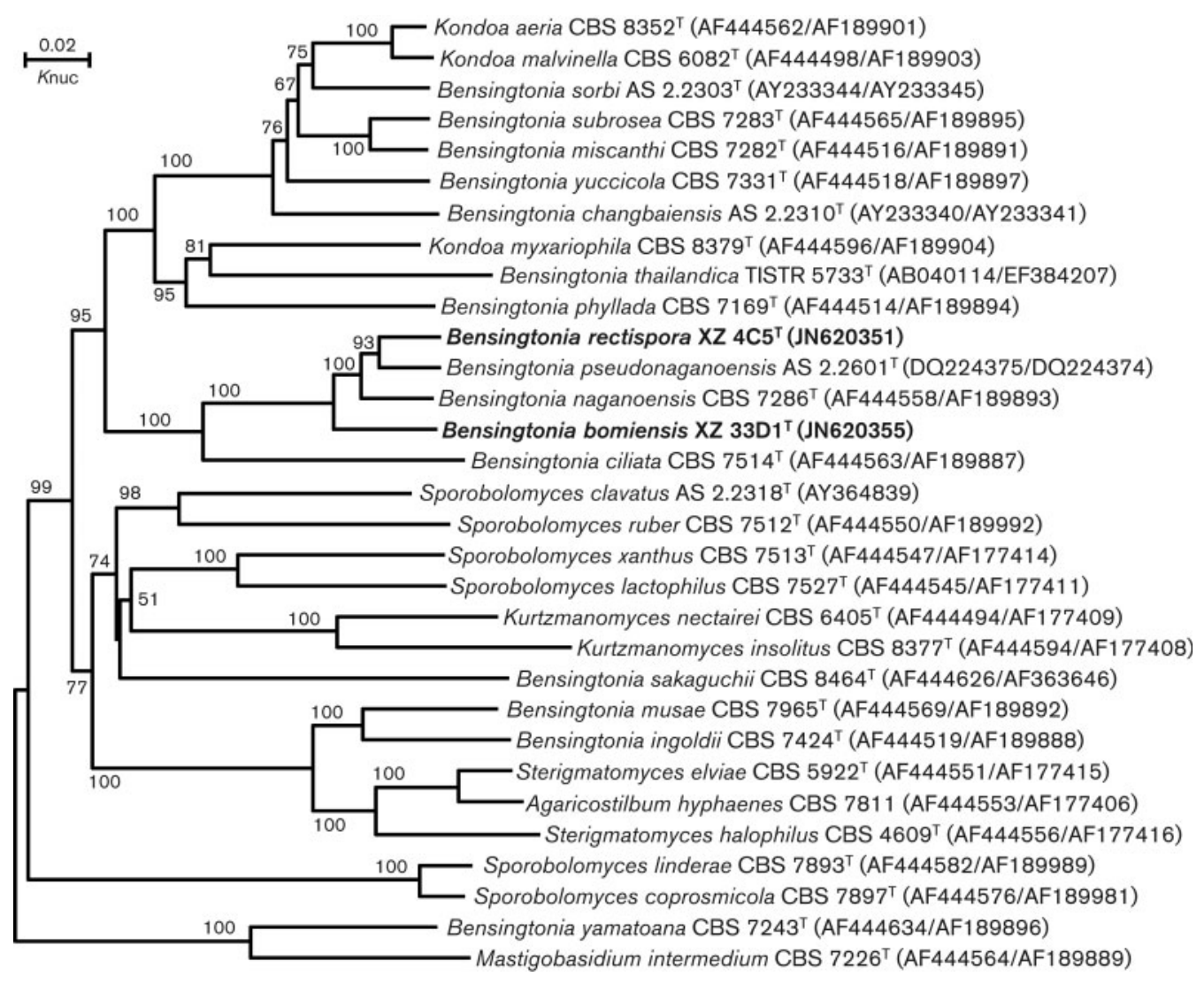

Fig. 1. Phylogenetic tree drawn from neighbour-joining analysis based on sequences of the ITS region (including 5.8S rRNA) and 26S rRNA gene D1/D2 domain, depicting the relationships of the species $B$. rectispora sp. nov. and $B$. bomiensis sp. nov. with closely related taxa. Bootstrap values $>50 \%$ from 1000 bootstrap replicates are shown. Reference sequences were retrieved from GenBank under the accession numbers indicated. 
$33 \mathrm{D} 1^{\mathrm{T}}$ were located in a well-supported clade together with B. ciliata, B. naganoensis and B. pseudonaganoensis (Fig. 1). The new strains were more closely related to the latter two species than to B. ciliata. Strain $\mathrm{XZ} 4 \mathrm{C}^{\mathrm{T}}$ differed from $B$. naganoensis and $B$. pseudonaganoensis by $8(1.2 \%)$ and 11 (1.6\%) substitutions in the D1/D2 domain, respectively.

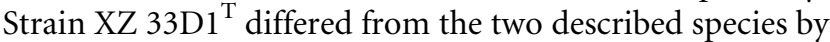
$16(2.4 \%)$ and $17(2.5 \%)$ substitutions in the D1/D2 domain, respectively. In the ITS region, the two novel strains $\mathrm{XZ} 4 \mathrm{C5}^{\mathrm{T}}$ and $\mathrm{XZ} 33 \mathrm{D} 1^{\mathrm{T}}$ differed from the two closely related described species by $6-13 \%$ mismatches. The results suggest that the two groups represent two novel Bensingtonia species, for which the names Bensingtonia rectispora sp. nov. and Bensingtonia bomiensis sp. nov. are proposed.

It is apparent that more extensive molecular studies aiming to clarify the fine phylogenetic relationships among Bensingtonia and related basidiomycetous yeast species will be necessary for the reclassification of Bensingtonia as well as other polyphyletic basidiomycetous yeast genera. The addition of novel species to the phylogenetic trees will be helpful for the recognition of monophyletic groups, as shown in our previous studies (Wang \& Bai, 2008; Wang et al., 2011). The present study strengthens the monophyletic nature of the B. ciliata clade, on which redefinition of the genus Bensingtonia will be based. Although $B$. bomiensis is only represented by a single strain at present, its clear phylogenetic isolation suggests that the proposal of the novel species is beyond question.

\section{Morphology and physiology}

All the strains studied formed cream to brownish colonies and ellipsoidal, elongate or cylindrical vegetative cells (Fig. $2 \mathrm{a}$ and Fig. 3a). The major ubiquinone of all these strains was CoQ-9. They produced bilaterally symmetrical ballistoconidia on corn meal agar. The above characteristics are typical for the genus Bensingtonia. The ballistoconidia formed by $B$. rectispora strains were nearly straight (Fig. $2 \mathrm{~b}$ ), whereas those formed by B. bomiensis strain XZ 33D1 ${ }^{\mathrm{T}}$ were usually curved (Fig. 3b). Sexual cycles were not observed in the cultures of single strains of the two novel species or mixed strains of $B$. rectispora compared on various media.

Although B. rectispora is distinguishable from its close relatives by its ballistoconidium morphology, this novel species exhibited similar physiological characters to $B$. bomiensis, B. naganoensis and B. pseudonaganoensis (Table 2 ). These four closely related species clearly differed from $B$. ciliata in the assimilation reactions of sucrose, melezitose, ethanol and citric acid (Table 2).

\section{Latin diagnosis of Bensingtonia rectispora F.-Y. Bai et Q.-M. Wang sp. nov.}

In YM (Difco) liquido post dies 5 ad $17^{\circ} \mathrm{C}$, cellulae vegetativae longae ellipsoideae vel cylindricus, $2.5-5.6 \times 5.0-11.0 \mu \mathrm{m}$,
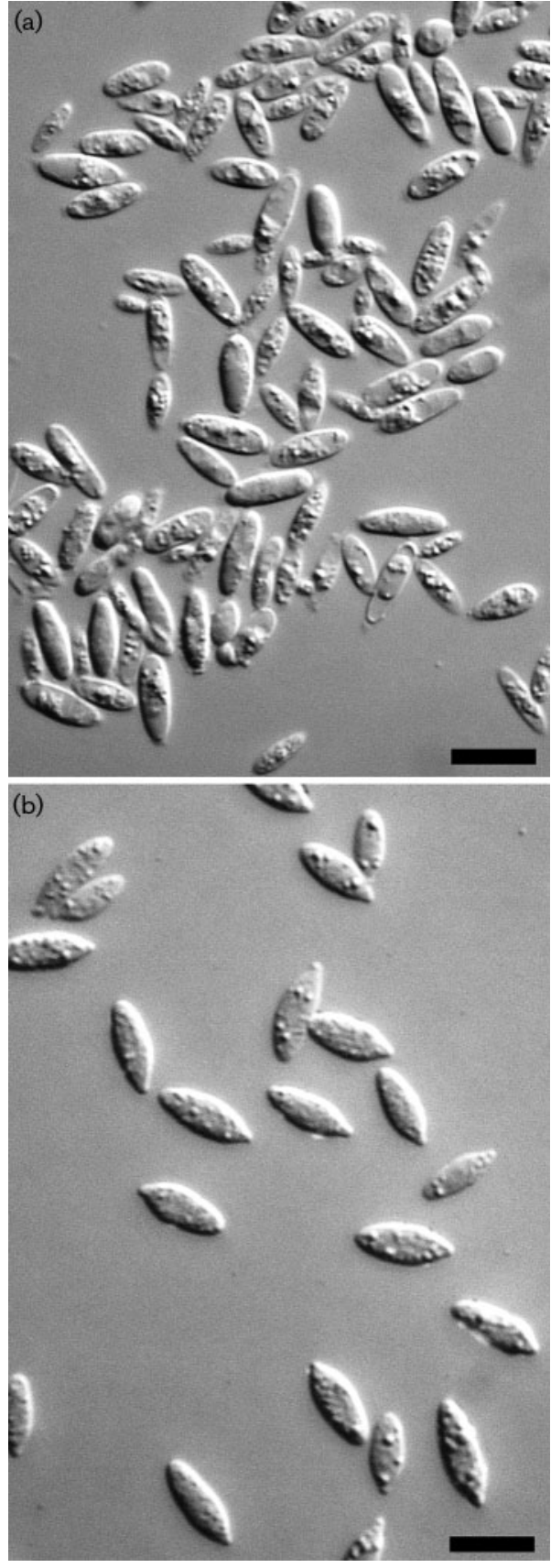

Fig. 2. Bensingtonia rectispora sp. nov. $\mathrm{XZ} 4 \mathrm{C} 5^{\top}$ vegetative cells grown in $\mathrm{YM}$ broth for 5 days at $17{ }^{\circ} \mathrm{C}$ (a) and ballistoconidia produced on corn meal agar after 5 days at $17^{\circ} \mathrm{C}$ (b). Bars, $10 \mu \mathrm{m}$.

singulae. Sedimentum formatur. Post unum mensem ad $17{ }^{\circ} \mathrm{C}$, sedimentum formatur. In agaro YM post unum mensem ad $17{ }^{\circ} \mathrm{C}$, cultura brunneusa-cremea, glabra, butyracea, margine glabra. Pseudomycelium non formatur. Ballistosporae longae ellipsoideae vel allantoidia, 2.2-5.5 $\times 5.0-11.0 \mu \mathrm{m}$. Glucosum, saccharosum, maltosum, trehalosum, melezitosum, glycerolum (vel lente) et D-mannitolum (lente vel exigue) assimilantur at non galactosum, L-sorbosum (lente vel exigue), 


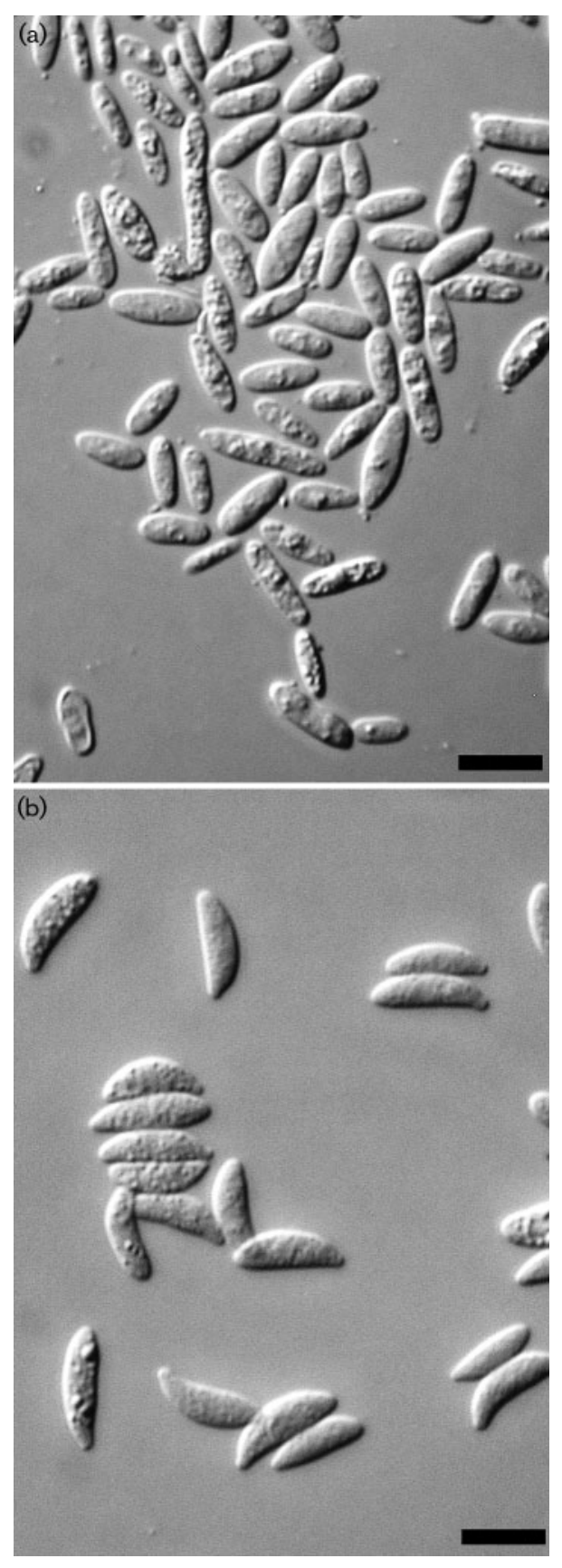

Fig. 3. Bensingtonia bomiensis sp. nov. $\mathrm{XZ} 33 \mathrm{D} 1^{\top}$ vegetative cells grown in $\mathrm{YM}$ broth for 5 days at $17{ }^{\circ} \mathrm{C}$ (a) and ballistoconidia produced on corn meal agar after 5 days at $17{ }^{\circ} \mathrm{C}$ (b). Bars, $10 \mu \mathrm{m}$.

cellobiosum, lactosum, melibiosum, raffinosum, inulin, amylum solubile, D-xylosum (vel exigue), L-arabinosum, D-arabinosum, D-ribosum, L-rhamnosum, D-glucosaminum, methanolum, ethanolum, erithritolum, ribitolum, galactitolum, glucitolum, methyl $\alpha$-D-glucosidum, salicinum, acidum DL-lacticum, acidum succinicum, acidum citricum, inositolum nec hexadecanum. Ammonium sulfatum, kalium nitricum et cadaverinum
Table 2. Physiological characteristics that differentiate $B$. rectispora sp. nov. and $B$. bomiensis sp. nov. from closely related species

Taxa: 1, B. rectispora sp. nov.; 2, B. bomiensis sp. nov.; 3, B. naganoensis (Nakase et al., 2011); 4, B. pseudonaganoensis (Wang et al., 2006); 5, B. ciliata (Nakase et al., 2011). +, Positive; -, negative; 1 , latent; s, slowly positive; $w$, weak.

\begin{tabular}{|c|c|c|c|c|c|}
\hline Assimilation reaction & 1 & 2 & 3 & 4 & 5 \\
\hline Sucrose & + & + & + & + & - \\
\hline Cellobiose & - & - & $+/ \mathrm{s}$ & $+/ \mathrm{w}$ & - \\
\hline Trehalose & + & + & $+1-$ & + & $+/ \mathrm{s}$ \\
\hline Melibiose & - & - & $+/ \mathrm{s}$ & $+/ \mathrm{w}$ & - \\
\hline Raffinose & - & - & $+/ \mathrm{s}$ & $+/ \mathrm{w}$ & - \\
\hline Melezitose & + & + & + & + & - \\
\hline Ethanol & - & - & - & - & $+/ \mathrm{s}$ \\
\hline Ribitol & - & - & $+1-$ & + & $+/ \mathrm{w}$ \\
\hline D-Glucitol & - & - & $+/ \mathrm{s}$ & + & $+/ \mathrm{s}$ \\
\hline Methyl $\alpha$-D-glucoside & - & 1 & - & - & - \\
\hline Succinic acid & - & - & $+1-$ & - & + \\
\hline Citric acid & - & - & - & - & + \\
\hline
\end{tabular}

assimilantur at non natrum nitrosum, L-lysinum nec ethylaminum. Ad crescentiam vitaminum necessarium est. Maxima temperatura crescentiae: $23{ }^{\circ} \mathrm{C}$. Materia amyloidea iodophila non formatur. Urea finditur. Diazonium caeruleum B positivum. Ubiquinonum majus: CoQ-9. Typus: isolatus ex folio bamboo, $\mathrm{XZ} 4 \mathrm{C}^{\mathrm{T}}$, depositus in collectione China General Microbiological Culture Collection Center, Academia Sinica $\left(=\right.$ CGMCC $2.02635^{\mathrm{T}}=$ CBS $\left.10710^{\mathrm{T}}\right)$.

\section{Description of Bensingtonia rectispora F.-Y. Bai \& Q.-M. Wang sp. nov.}

Bensingtonia rectispora [rec.ti.spo'ra. L. adj. rectus straight; N.L. n. spora (from Gr. n. spora a seed) spore; N.L. n. rectispora (nominative in apposition) straight spore, referring to the ballistoconidium morphology of this species].

In YM broth, after 5 days at $17{ }^{\circ} \mathrm{C}$, cells are long ellipsoids or cylindrical, $2.5-5.6 \times 5.0-11.0 \mu \mathrm{m}$, and occur singly; budding is polar and sediment is formed. After 1 month at $17^{\circ} \mathrm{C}$, sediment is present. On YM agar, after 1 month at $17^{\circ} \mathrm{C}$, the streak culture is brownish cream, butyrous and smooth. The margin is entire. In Dalmau plate culture on corn meal agar, pseudohyphae are not formed. Ballistoconidia are long ellipsoids or allantoid, $2.2-5.5 \times 5.0-11.0 \mu \mathrm{m}$. Fermentation is negative. Glucose, sucrose, maltose, trehalose, melezitose, glycerol (may be delayed) and D-mannitol (delayed or weak) are assimilated. Galactose, cellobiose, lactose, melibiose, raffinose, inulin, soluble starch, L-arabinose, D-arabinose, D-ribose, L-rhamnose, D-glucosamine, methanol, ethanol, erythritol, ribitol, galactitol, D-glucitol, methyl $\alpha$-Dglucoside, salicin, DL-lactic acid, succinic acid, citric acid, inositol and hexadecane are not assimilated; assimilation of L-sorbose may be negative, delayed or weak and assimilation of D-xylose may be negative or weak. Ammonium sulfate, 
potassium nitrate and cadaverine dihydrochloride are assimilated. Sodium nitrite, L-lysine and ethylamine hydrochloride are not assimilated. Maximum growth temperature is $23{ }^{\circ} \mathrm{C}$. Growth in vitamin-free medium is negative. Starch-like substances are not produced. Growth on $50 \%$ $(\mathrm{w} / \mathrm{w})$ glucose-yeast extract agar is negative. Urease activity is positive. Diazonium Blue B reaction is positive. The major ubiquinone is CoQ-9.

The type strain is $\mathrm{XZ} 4 \mathrm{C}^{\mathrm{T}}\left(=\mathrm{CGMCC} 2.02635^{\mathrm{T}}=\mathrm{CBS}\right.$ $10710^{\mathrm{T}}$ ), isolated from a leaf of bamboo collected in Nyingchi county, Tibet, China, in July 2004.

\section{Latin diagnosis of Bensingtonia bomiensis F.-Y. Bai et Q.-M. Wang sp. nov.}

In YM (Difco) liquido post dies 5 ad $17{ }^{\circ} \mathrm{C}$, cellulae vegetativae ellipsoideae vel cylindrica, 2.6-5.8 $\times 5.2-11.5 \mu \mathrm{m}$, singulae. Sedimentum formatur. Post unum mensem ad $17{ }^{\circ} \mathrm{C}$, annulus et sedimentum formantur. In agaro YM post unum mensem ad $17^{\circ} \mathrm{C}$, cultura brunneusa-cremea, glabra, butyracea, margine glabra. Pseudomycelium non formatur. Ballistosporae allantoidia vel reniformia, 2.5-6.5 $\times 6.0-12.0 \mu \mathrm{m}$. Fermentatio nulla. Glucosum, saccharosum, maltosum, trehalosum, melezitosum, L-rhamnosum (exigue), glycerolum, D-mannitolum (lente) et methyl $\alpha$-D-glucosidum (lente) assimilantur at non galactosum, L-sorbosum, cellobiosum, lactosum, melibiosum, raffinosum, inulin, amylum solubile, D-xylosum, L-arabinosum, D-arabinosum, D-ribosum, D-glucosaminum, methanolum, ethanolum, erithritolum, ribitolum, galactitolum, glucitolum, salicinum, acidum DL-lacticum, acidum succinicum, acidum citricum, inositolum nec hexadecanum. Ammonium sulfatum, kalium nitricum et cadaverinum assimilantur at non natrum nitrosum, L-lysinum nec ethylaminum. Ad crescentiam vitaminum non necessarium est. Maxima temperatura crescentiae: $22{ }^{\circ} \mathrm{C}$. Materia amyloidea iodophila non formatur. Urea finditur. Diazonium caeruleum B positivum. Ubiquinonum majus: CoQ-9. Typus: isolatus ex folio plantae incognitae, $\mathrm{XZ} 33 \mathrm{D}^{\mathrm{T}}$, depositus in collectione China General Microbiological Culture Collection Center, Academia Sinica $\left(=\right.$ CGMCC $2.02670^{\mathrm{T}}=$ CBS $\left.10713^{\mathrm{T}}\right)$.

\section{Description of Bensingtonia bomiensis F.-Y. Bai \& Q.-M. Wang sp. nov.}

Bensingtonia bomiensis (bo.mi.en'sis. N.L. fem. adj. bomiensis pertaining to Bomi county, Tibet, referring to the geographical origin of the type strain of this species).

In YM broth, after 5 days at $17{ }^{\circ} \mathrm{C}$, cells are long ellipsoids or cylindrical, $2.6-5.8 \times 5.2-11.5 \mu \mathrm{m}$, and occur singly; budding is polar and sediment is formed. After 1 month at $17{ }^{\circ} \mathrm{C}$, a ring and sediment are present. On YM agar after 1 month at $17{ }^{\circ} \mathrm{C}$, the streak culture is brownish cream, butyrous and smooth. The margin is entire. In Dalmau plate culture on corn meal agar, pseudohyphae are not formed. Ballistoconidia are allantoid or reniform, 2.5$6.5 \times 6.0-12.0 \mu \mathrm{m}$. Fermentation is negative. Glucose, sucrose, maltose, trehalose, melezitose, L-rhamnose (weak), glycerol, D-mannitol (delayed) and methyl $\alpha$-D-glucoside (delayed) are assimilated. Galactose, L-sorbose, cellobiose, lactose, melibiose, raffinose, inulin, soluble starch, Dxylose, L-arabinose, D-arabinose, D-ribose, D-glucosamine, methanol, ethanol, erythritol, ribitol, galactitol, D-glucitol, salicin, DL-lactic acid, succinic acid, citric acid, inositol and hexadecane are not assimilated. Ammonium sulfate, potassium nitrate and cadaverine dihydrochloride are assimilated. Sodium nitrite, L-lysine and ethylamine hydrochloride are not assimilated. Maximum growth temperature is $22{ }^{\circ} \mathrm{C}$. Growth in vitamin-free medium is positive (weak). Starch-like substances are not produced. Growth on $50 \%(\mathrm{w} / \mathrm{w})$ glucose-yeast extract agar is negative. Urease activity is positive. Diazonium Blue B reaction is positive. The major ubiquinone is CoQ-9.

The type strain is XZ $33 \mathrm{D} 1^{\mathrm{T}}\left(=\mathrm{CGMCC} 2.02670^{\mathrm{T}}=\mathrm{CBS}\right.$ $\left.10713^{\mathrm{T}}\right)$, isolated from a leaf of an unidentified plant collected in Bomi county, Tibet, China, in July 2004.

\section{Acknowledgements}

This study was supported by grants from the National Natural Science Foundation of China (NSFC) (nos 30970013, 30825002 and 31010103902) and from the Knowledge Innovation Program of the Chinese Academy of Sciences (KSCX2-YW-Z-0936).

\section{References}

Bai, F. Y., Zhao, J. H., Takashima, M., Jia, J. H., Boekhout, T. \& Nakase, T. (2002). Reclassification of the Sporobolomyces roseus and Sporidiobolus pararoseus complexes, with the description of Sporobolomyces phaffii sp. nov. Int J Syst Evol Microbiol 52, 2309-2314.

Boekhout, T., Fonseca, A., Sampaio, J. P., Bandoni, R. J., Fell, J. W. \& Kwon-Chung, K. J. (2011). Discussion of teleomorphic and anamorphic basidiomycetous yeasts. In The Yeasts, A Taxonomic Study, 5th edn, pp. 1339-1372. Edited by C. P. Kurtzman, J. W. Fell \& T. Boekhout. Amsterdam: Elsevier.

Fell, J. W., Boekhout, T., Fonseca, A., Scorzetti, G. \& StatzellTallman, A. (2000). Biodiversity and systematics of basidiomycetous yeasts as determined by large-subunit rDNA D1/D2 domain sequence analysis. Int J Syst Evol Microbiol 50, 1351-1371.

Felsenstein, J. (1985). Confidence limits on phylogenies: an approach using the bootstrap. Evolution 39, 783-791.

Hamamoto, M. \& Nakase, T. (2000). Phylogenetic analysis of the ballistoconidium-forming yeast genus Sporobolomyces based on $18 \mathrm{~S}$ rDNA sequences. Int J Syst Evol Microbiol 50, 1373-1380.

Ingold, C. T. (1986). Bensingtonia ciliata gen. et sp. nov., a ballistosporic fungus. Trans Br Mycol Soc 86, 325-328.

Kimura, M. (1980). A simple method for estimating evolutionary rates of base substitutions through comparative studies of nucleotide sequences. J Mol Evol 16, 111-120.

Kurtzman, C. P., Fell, J. W., Boekhout, T. \& Robert, V. (2011). Methods for isolation, phenotypic characterization and maintenance of yeasts. In The Yeasts, A Taxonomic Study, 5th edn, pp. 87-110. Edited by C. P. Kurtzman, J. W. Fell \& T. Boekhout. Amsterdam: Elsevier.

Makimura, K., Murayama, S. Y. \& Yamaguchi, H. (1994). Detection of a wide range of medically important fungi by the polymerase chain reaction. J Med Microbiol 40, 358-364. 
Nakase, T. \& Boekhout, T. (1988). Emendation of the genus Bensingtonia Ingold. J Gen Appl Microbiol 34, 433-437.

Nakase, T. \& Suzuki, M. (1986). Bullera megalospora, a new species of yeast forming large ballistospores isolated from dead leaves of Oryza sativa, Miscanthus sinensis and Sasa sp. in Japan. J Gen Appl Microbiol 32, 225-240.

Nakase, T. \& Takashima, M. (1993). A simple procedure for the high frequency isolation of new taxa of ballistosporous yeasts living on the surfaces of plants. RIKEN Review 3, 33-34.

Nakase, T., Bai, F. Y. \& Boekhout, T. (2011). Bensingtonia Ingold emend. Nakase \& Boekhout. In The Yeasts, A Taxonomic Study, 5th edn, pp. 1607-1622. Edited by C. P. Kurtzman, J. W. Fell \& T. Boekhout. Amsterdam: Elsevier.

Saitou, N. \& Nei, M. (1987). The neighbor-joining method: a new method for reconstructing phylogenetic trees. Mol Biol Evol 4, 406425.

Scorzetti, G., Fell, J. W., Fonseca, A. \& Statzell-Tallman, A. (2002). Systematics of basidiomycetous yeasts: a comparison of large subunit D1/D2 and internal transcribed spacer rDNA regions. FEMS Yeast Res 2, 495-517.

Takashima, M., Suh, S. O. \& Nakase, T. (1995). Phylogenetic relationships among species of the genus Bensingtonia and related taxa based on the small subunit ribosomal DNA sequences. J Gen Appl Microbiol 41, 131-141.
Thompson, J. D., Gibson, T. J., Plewniak, F., Jeanmougin, F. \& Higgins, D. G. (1997). The CLUSTAL_X windows interface: flexible strategies for multiple sequence alignment aided by quality analysis tools. Nucleic Acids Res 25, 4876-4882.

Wang, Q. M. \& Bai, F. Y. (2008). Molecular phylogeny of basidiomycetous yeasts in the Cryptococcus luteolus lineage (Tremellales) based on nuclear rRNA and mitochondrial cytochrome $b$ gene sequence analyses: proposal of Derxomyces gen. nov. and Hannaella gen. nov., and description of eight novel Derxomyces species. FEMS Yeast Res 8, 799-814.

Wang, Q. M., Bai, F. Y., Zhao, J. H. \& Jia, J. H. (2003). Bensingtonia changbaiensis sp. nov. and Bensingtonia sorbi sp. nov., novel ballistoconidium-forming yeast species from plant leaves. Int J Syst Evol Microbiol 53, 2085-2089.

Wang, Q. M., Jia, J. H. \& Bai, F. Y. (2006). Bensingtonia pseudonaganoensis sp. nov., a novel ballistoconidium-forming yeast species isolated from plant leaves. Antonie van Leeuwenhoek 89, 261-266.

Wang, Q. M., Bai, F. Y., Fungsin, B., Boekhout, T. \& Nakase, T. (2011). Proposal of Mingxiaea gen. nov. for the anamorphic basidiomycetous yeast species in the Bulleribasidium clade (Tremellales) based on molecular phylogenetic analysis, with six new combinations and four novel species. Int J Syst Evol Microbiol 61, 210-219.

Yamada, Y. \& Kondo, K. (1973). Coenzyme Q system in the classification of the yeast genera Rhodotorula and Cryptococcus and the yeast like genera Sporobolomyces and Rhodosporidium. J Gen Appl Microbiol 19, 59-77. 